\title{
Applicability of management tools to the correction of weaknesses in family dairy farms in the Western Amazon
}

\author{
Aplicabilidade de ferramentas de gestão na correção de pontos \\ fracos em propriedades leiteiras de agricultura familiar na \\ Amazônia ocidental
}

\author{
Eduardo Mitke Brandão Reis ${ }^{1}$; Marcos Aurélio Lopes ${ }^{2 *}$; Fabiana Alves Demeu ${ }^{3}$; \\ Fábio Raphael Pascotti Bruhn ${ }^{4}$; André Luis Ribeiro Lima ${ }^{5}$; Gideon Carvalho de \\ Benedicto $^{5}$; Djalma Ferreira Pelegrini ${ }^{6}$
}

\begin{abstract}
The aim of this study was to analyse the applicability of management tools associated with technical assistance to family dairy farms with the aim of identifying and correcting weaknesses. A total of 100 dairy farms located in the mesoregion of the Acre Valley, in the Western Amazon, were analysed from March 2016 to March 2017. The data used were collected via a semi-structured form containing 549 questions, through on-site observation and from the owners during the diagnosis. To define the weaknesses, a multidisciplinary team used the brainstorming management tool. The main weaknesses obtained using the GUT Matrix, in descending order, were: a lack of drinking fountains, no vaccination of all heifers against brucellosis, low body condition of cows at calving, and a calving interval longer than 12 months. Based on the ranking of the weaknesses, the research team defined the management tools to be used to correct or at least mitigate the weaknesses: PDCA, $5 \mathrm{~W} 2 \mathrm{H}$, and/or a fishbone diagram. Among the 20 most graded weaknesses, the management tools used by the extensionist technician obtained significant results in solving the problems. It was concluded that it is possible to adapt and apply the management tools used in other activities to dairy farming and that they can be used continuously for management or specifically to establish a plan or project.
\end{abstract}

Key words: Amazonia. Dairy cattle. Diagnosis. Productivity. Profitability.

\section{Resumo}

Objetivou-se analisar a aplicabilidade das ferramentas de gestão associada à assistência técnica em propriedades leiteiras de agricultura familiar visando o levantamento e a correção de pontos fracos.

1 Prof. Dr., Universidade Federal do Acre, UFAC, Centro de Ciências Biológicas e da Natureza, Rio Branco, AC, Brasil. E-mail: edumitke@hotmail.com

2 Prof. Dr. Titular, Universidade Federal de Lavras, UFLA, Departamento de Medicina Veterinária, Lavras, MG, Brasil. E-mail: malopes@dmv.ufla.br

3 Prof ${ }^{a}$ M.e, Instituto Federal de Rondônia, IFRO, Ariquemes, RO. Discente do Curso de Doutorado do Programa de Pós-Graduação em Ciências Veterinárias, UFLA, Lavras, MG, Brasil. E-mail: fabiana.alves@ifro.edu.br

4 Prof. Dr., Universidade Federal de Pelotas, UFPel, Departamento de Veterinária Preventiva, Capão do Leão, RS, Brasil. E-mail; fabio_rpb@yahoo.com.br

5 Profs. Drs., UFLA, Departamento de Administração e Economia, Lavras, MG, Brasil. E-mail: andreluisnep@yahoo.com.br; gideon.benedicto@dae.ufla.br

6 Pesquisador Dr., Empresa de Pesquisa Agropecuária de Minas Gerais, EPAMIG, Belo Horizonte, MG, Brasil. E-mail: djalmapelegrini@uol.com.br

* Author for correspondence. 
Foram analisadas 100 propriedades leiteiras, localizadas na Mesorregião do Vale do Acre, na Amazônia Ocidental, no período de março de 2016 a março de 2017. Os dados utilizados foram coletados a partir de um formulário semiestruturado, contendo 549 questões, por meio da observação in loco, bem como por respostas obtidas com os proprietários, durante a realização do diagnóstico. Para definição dos pontos fracos, uma equipe multidisciplinar utilizou a ferramenta de gestão Brainstorming. Os principais pontos fracos encontrados, em ordem decrescente, utilizando-se a Matriz GUT, foram: inexistência de bebedouros, não vacinar todas as bezerras contra brucelose, baixa condição corporal das vacas ao parto e intervalo de partos maior que 12 meses. A partir do ranqueamento dos pontos fracos, a equipe de pesquisadores definiu quais ferramentas de gestão seriam utilizadas: PDCA, 5W2H e/ou Diagrama de Ishikawa, visando corrigi-los ou, pelo menos, amenizá-los. Entre os 20 pontos fracos mais pontuados, as ferramentas de gestão utilizadas pelo técnico extensionista obtiveram resultados expressivos na resolução dos problemas. Concluiu-se que é possível adequar e aplicar as ferramentas de gestão, tão utilizadas em outras atividades, à pecuária leiteira; podendo ser usadas de forma contínua para o gerenciamento ou de forma pontual no estabelecimento de um plano ou projeto.

Palavras-chave: Amazônia. Bovinocultura leiteira. Diagnóstico. Produtividade. Rentabilidade.

\section{Introduction}

Although Brazil is the fourth-largest producer of bovine milk worldwide, the annual productivity of around $1,680 \mathrm{~L}$ per cow is low compared with that in the United States ( $9,850 \mathrm{~L}$ per cow), the European Union (6,140 L per cow), Argentina (5,830 L per cow) and New Zealand (4,060 L per cow) (PEREIRA et al., 2016). Brazilian dairy farming has very low zootechnical, economic and productivity rates, making it unattractive. In addition, the productive sector is underdeveloped, especially in the management area (NOVO; SCHIFFLER, 2006; SILVA et al., 2015). Producers' lack of preparation affects their farm negatively, providing low economic returns and even losses, besides discouraging them from continuing milk production. Therefore, cowmen need to adapt, think and act as rural entrepreneurs with a managerial vision of their activity (CREPALDI, 1998), regardless of whether they are a small, medium or large producer (LOPES et al., 2004). According to Godinho and Carvalho (2009), there are still a large number of dairy farmers who do not view their activity as a rural enterprise. Good rural property management is essential for achieving sustainable development.

Several transformations have contributed to the fact that milk producers could reflect on the need to manage their activity well, becoming more efficient and hence competitive (LOPES et al.,
2004). Good management provides conditions for rural producers to develop the agricultural sector. Management tools can aid in this task, contributing improvements to producers' socioeconomic conditions, strategic decisions and advances in productive activity (FARIAS et al., 2013). There are techniques for business use that aim to find solutions to managerial problems, and they can help entrepreneurs in decision making within their productive process, since they guide them in the observation, identification and analysis of problems (MEIRELES, 2006). When applied, they generate possibilities to obtain greater profits in that activity (ROBERTI; SANTANA, 2013). Wolf (2012) reported several reasons for the non-use of tools to aid management, including the cost, a lack of time management, and a lack of understanding of the theme. He also stated that, to modify this framework, it would be necessary to implement an educational programme in management tools and a broader knowledge of risk management.

Bonamigo et al. (2014) investigated the use of management tools in agribusiness; however, none of the studies have referred to the evaluation and use of such tools in dairy cattle. Most of the studies that dealt with the use of these tools focused on secondary- and tertiary-sector enterprises (ANDRADE; BOFF, 2014; AMORIM et al., 2015); their use in the primary sector has been quite rare 
(ALVES et al., 2007).

In this context, the following question arises: Can management tools be applied to dairy farms, especially family farming? Based on the importance of the theme and the current situation of dairy farming in Brazil, besides the scarcity of scientific articles on the theme, the objective was to study 100 family dairy farms and analyse the applicability of management tools, aiming to identify and correct weaknesses and hence increase productivity and profitability. Specifically, the study also intended to validate a question form to perform the diagnosis in dairy farms, to identify weaknesses and to recommend a management tool to be used for each diagnosed weakness.

\section{Material and Methods}

The research was performed in 100 dairy farms under the family farming regime located in the mesoregion of the Acre Valley, in the Western Amazon, from March 2016 to March 2017. The studied geographical area is composed of 14 municipalities: Acrelândia (6 producers), Assis Brasil (3), Brasiléia (7), Bujari (4), Capixaba (8), Epitaciolândia (7), Manoel Urbano (4), Plácido de Castro (11), Porto Acre (6), Rio Branco (16), Santa Rosa dos Purus (5), Sena Madureira (12), Senador Guiomard (9) and Xapuri (2). The producers were interviewed on their properties, besides being randomly selected (GUDKOVAet al., 2016) from the list provided by the State Secretariat of Agriculture (SEAP) Secretariat of Agroforestry extension and family farming of the state of Acre (SEAPROF), regardless of the milk volume marketed or the production system adopted. The definition of the number of interviewees in the sample $(n=100)$ was estimated according to Barbetta (2003), considering a maximum sampling error of $5 \%$.

For the interviews and diagnosis, a semistructured form containing 549 questions, developed by Lopes et al. (2016b), was used. These questions are divided into themes: producer and property registry (52 questions), herd characterization (12 questions), and milk production (485 questions). The last topic includes the farming system, agricultural practices, nutritional management, infrastructure, zootechnical bookkeeping, animal identification, reproductive management, milk quality, milking management, heifer breeding, sanitary control and environmental management. The form also contains a checklist of photos, which helps researchers in recording details that are difficult to describe and remember; this is useful in gathering strengths and weaknesses.

Secondly, the weaknesses found in the dairy farms were surveyed. To this end, the brainstorming management tool (ANDRADE; BOFF, 2014) was used. At this stage, each member of the multidisciplinary team, composed of veterinarians, zootechnicians, professors and managers, revealed their opinions in relation to each analysed item on the diagnostic form.

After defining the weaknesses, each researcher individually evaluated and graded from zero to five each item considered to be the most severe, the most urgent and having a tendency to worsen, using the management tool GUT Matrix (MEIRELES, 2006). The items were listed on a worksheet with the respective grades, and an average was estimated for the different grades assigned by each researcher. Accordingly, the weaknesses were ranked in descending order from the average grade. Aiming to select the most appropriate management tool for solving those problems, the team used the brainstorming tool (COLETTI et al., 2010) and selected the fishbone diagram (ISHIKAWA, 1985), a diagnostic tool (MIGUEL, 2006); the 5W2H (POLACINSKI et al., 2012), an action tool (MASSARONI; SCAVARDA, 2015); and PDCA (AGUIAR, 2006), an organizational tool (BEHR et al., 2008) in the mission to correct or at least minimize the diagnosed weaknesses. It is worth pointing out that, in the correction of a certain weakness, one or more tools may be used (LOPES et al., 2016a). 
Afterwards, the management tools were applied to 30 dairy farms, selected using non-probabilistic judgement sampling considering the following criteria: the availability and quality of zootechnical data; the consent and interest of the cowman in conducting the research; and the researcher's access to the evidence sources (LOPES et al., 2015). After the application of management tools, a new diagnosis was made in the 30 studied properties to evaluate their applicability and the efficiency of each one.

The results were tabulated using the Excel $^{\circledR}$ software and hence analysed descriptively and comparatively. For the data analysis, the McNemar statistical test was performed in the SPSS 20.0 software (IBM, 2011) to evaluate the significance of the differences observed in the responses at the two moments at which the diagnoses were performed (FISHER; VAN BELLE, 1993), before and after the application of the management tools in the properties.

\section{Results and Discussion}

The weaknesses found during the diagnosis, listed in descending order by the average grade attributed after using the GUT Matrix (MEIRELES, 2006), can be observed in Table 1. The higher grades indicate the weaknesses that should be prioritized in the attempt to equate or minimize them, since they have greater severity, greater urgency to be solved, and a greater tendency to worsen. In some of them, high standard deviation values are apparent, which indicate the divergence of opinions among technical researchers. The main problems are: a lack of drinking fountains, no vaccination of all heifers against brucellosis, low body condition of cows at calving, and a calving interval longer than 12 months.

The diagnosis was fundamental to identifying weaknesses that could compromise the productive and economic success of the studied dairy farms. This is beneficial because in many cases there is no need to expend large investments or substantial efforts to solve the problems, making the dairy properties promising. Based on the points listed, an action plan and goals can be accomplished in the short, medium and long term. The data collection, through the diagnosis performed, aimed at streamlining the decision making within the dairy properties. A brief discussion of the importance of each diagnosed weakness, as well as the recommendation of the management tool to be used, is presented in this study.

First weakness: a lack of drinking fountains in pastures

In $85 \%$ of the studied properties, the presence of drinking fountains was not observed. These, if well managed, offer cleaner water of better quality to the cattle reared in pastures, according to their ingestion needs, with better access, avoiding energy costs on the part of the animal in search of water besides hierarchical disputes. The use of drinking fountains in pasture cattle production increases productivity (TAVARES; BENEDETTI, 2012). Moreover, the use of watering places, such as streams and headwaters, can cause serious environmental impacts, since the direct access of cattle causes water quality problems due to the accumulation of manure and the silting of banks (OSBORNE et al., 2002).

This fact changes the physical aspects of water, such as its temperature, colour and turbidity, besides its organoleptic characteristics, for instance its appearance, taste and odour, and it can be rejected for drinking purposes (WHO, 1993). The quantity and quality of water are fundamental elements for the production process, since water directly interferes in cattle nutrition (BIZINOTO, 2002). Unfortunately, animals' water intake is often not considered to be a limiting factor, and much more attention is paid to other dietary nutrients. However, low water intake increases hematocrit values and blood urea concentration and reduces the respiratory rate, rumen contractions, live weight and milk production (RIBEIRO; BENEDETTI, 2011). 
Table 1. Grade attributed through the GUT Matrix to each weakness identified in the 100 studied dairy farms in the mesoregion of the Acre Valley from March to July 2017.

\begin{tabular}{|c|c|c|c|c|c|c|c|c|}
\hline \multirow[b]{2}{*}{ Weaknesses } & \multicolumn{8}{|c|}{ Grade attributed by the researchers from the multidisciplinary team* } \\
\hline & 1 & 2 & 3 & 4 & 5 & 6 & Average ** & SD \\
\hline $\begin{array}{l}\text { Lack of drinking fountains in pas- } \\
\text { tures }\end{array}$ & 125 & 125 & 125 & 125 & 125 & 125 & 125.00 & 0.00 \\
\hline $\begin{array}{l}\text { No vaccination of all heifers against } \\
\text { brucellosis }\end{array}$ & 125 & 125 & 125 & 125 & 125 & 125 & 125.00 & 0.00 \\
\hline $\begin{array}{l}\text { Inadequate (lean) body condition of } \\
\text { cows at calving }\end{array}$ & 125 & 125 & 125 & 100 & 125 & 125 & 121.00 & 10.00 \\
\hline $\begin{array}{l}\text { Cows dry on their own due to low } \\
\text { persistence of lactation }\end{array}$ & 125 & 64 & 125 & 125 & 125 & 125 & 115.00 & 25.00 \\
\hline $\begin{array}{l}\text { Calving interval greater than } 12 \\
\text { months }\end{array}$ & 100 & 100 & 125 & 125 & 125 & 100 & 113.00 & 14.00 \\
\hline $\begin{array}{l}\text { Non-realization of zootechnical } \\
\text { bookkeeping }\end{array}$ & 125 & 100 & 125 & 80 & 125 & 125 & 113.00 & 19.00 \\
\hline $\begin{array}{l}\text { Sick heifers are not separated from } \\
\text { healthy animals }\end{array}$ & 125 & 125 & 125 & 125 & 125 & 45 & 112.00 & 33.00 \\
\hline $\begin{array}{l}\text { Low vaccination rate against clos- } \\
\text { tridial diseases }\end{array}$ & 125 & 125 & 125 & 60 & 100 & 125 & 110.00 & 26.00 \\
\hline Inadequate herd composition & 125 & 100 & 125 & 125 & 100 & 80 & 109.00 & 19.00 \\
\hline $\begin{array}{l}\text { Performing brucellosis tests only } \\
\text { when animals are acquired }\end{array}$ & 125 & 125 & 80 & 125 & 75 & 125 & 109.00 & 25.00 \\
\hline Non-realization of tuberculosis exams & 125 & 125 & 80 & 125 & 75 & 125 & 109.00 & 25.00 \\
\hline Lack of sanitary calendar & 80 & 100 & 125 & 125 & 75 & 125 & 105.00 & 23.00 \\
\hline $\begin{array}{l}\text { Do not restrict the use of doramectin } \\
\text { based vermifuge in lactating cows }\end{array}$ & 125 & 125 & 125 & 125 & 1 & 125 & 104.00 & 51.00 \\
\hline $\begin{array}{l}\text { The criterion for drying a cow is pro- } \\
\text { duction }\end{array}$ & 125 & 64 & 125 & 60 & 125 & 125 & 104.00 & 33.00 \\
\hline Average infestation of ticks in cows & 100 & 64 & 125 & 125 & 75 & 125 & 102.00 & 27.00 \\
\hline $\begin{array}{l}\text { Average infestation of horn flies in } \\
\text { heifers }\end{array}$ & 100 & 64 & 125 & 125 & 75 & 125 & 102.00 & 27.00 \\
\hline Age at first calving of 36 months & 125 & 100 & 125 & 125 & 36 & 100 & 102.00 & 34.00 \\
\hline Do not make heat observation & 125 & 80 & 125 & 125 & 125 & 18 & 100.00 & 44.00 \\
\hline $\begin{array}{l}\text { Non-use of soil conservation prac- } \\
\text { tices }\end{array}$ & 125 & 125 & 125 & 80 & 60 & 80 & 99.00 & 29.00 \\
\hline $\begin{array}{l}\text { Heifers do not receive concentrate } \\
\text { after the seventh day }\end{array}$ & 125 & 64 & 125 & 125 & 125 & 27 & 99.00 & 43.00 \\
\hline $\begin{array}{l}\text { They did not seek to identify the } \\
\text { cause of abortions }\end{array}$ & 125 & 125 & 80 & 80 & 45 & 125 & 97.00 & 34.00 \\
\hline
\end{tabular}

* Multiplication of grades from zero to five for the aspects of gravity $(\mathrm{G})$, urgency $(\mathrm{U})$ and trend $(\mathrm{T})$;

**: Simple arithmetic mean; SD: standard deviation. 
Limiting water consumption reduces animals' performance faster and more drastically than any other nutrient deficiency (BOYLES et al., 1988). Cattle need a constant supply of abundant, good-quality and clean water to ensure normal fermentation and metabolism in the rumen, to maintain the flow of food in the digestive tract, to favour good digestion and the absorption of nutrients and to supply the demands of body tissues (ADAMS; SHARPE, 1995). Water intake has a direct impact on the productive performance of cattle reared in pastures. According to Marino (2006), a bovine of $450 \mathrm{~kg}$ at a room temperature of $27^{\circ} \mathrm{C}$ consumes $55 \mathrm{~L} /$ day. Benedetti (2009) reported that the minimum requirement is $45 \mathrm{~L} / \mathrm{head} /$ day or about 8-9 litres/100 kg live weight under proper management conditions.

Management tool proposed to solve the weakness of a lack of drinking fountains in pastures: $5 \mathrm{~W} 2 \mathrm{H}$

The management tool proposed to solve this problem is 5W2H (LISBOA; GODOY, 2012), since this type of problem is specific and does not require several people. It consists of the answer to seven questions used to implement solutions:

a) What? What is the activity? What is the topic? Answer: Implement drinking fountains in pastures.

b) Who? Who conducts the operation? Which is the responsible team? Answer: Technical team (researcher) of the dairy farm.

c) Where? Where will the operation be conducted? On which site? Answer: Site evaluation to prevent animals from having to move too far looking for water.

d) Why? Why is the operation necessary? Why is the activity necessary? Answer: To meet the needs of the animals and improve production and productivity. e) When? When will it be done? When will the activity begin? Answer: Immediately.

f) How? How will the operation be conducted? In what way? Answer: By installing drinking fountains at pasture sites.

g) How much does it cost to make the change? How much will the operation cost? Answer: Evaluation according to the amount of pastures, animals and material to be used in the drinking fountain.

Second weakness: no vaccination of all heifers against brucellosis

In $5 \%$ of the studied dairy farms, heifers were not vaccinated against brucellosis. Bovine brucellosis is a chronic disease of domestic and wild animals caused by Brucella abortus, an intracellular bacterium with a large capacity to invade, survive for long periods and multiply within host cells (POESTER et al., 2013). The economic importance attributed to this disease is based on the direct losses resulting from the death of animals, the decrease in weight gain, the decrease in milk production, early disposal, the condemnation of carcasses at slaughter (SOUZA et al., 2014), sanitary barriers, property interdiction (BRASIL, 2006) and public health problems (MOCCI et al., 2014). In herds infected with brucellosis, a decrease in meat and milk production of around $25 \%$ and a decrease in the production of heifers of around $15 \%$ are estimated (BERNUÉS et al., 1997; MIRANDA et al., 2008). According to Santos et al. (2013), for every $1 \%$ variation in the prevalence rate of bovine brucellosis in Brazil, the cost of the disease is estimated to be $\mathrm{R} \$ 155$ million. These economic losses comprise more than $0.3 \%$ of the Brazilian gross domestic product (GDP) generated by farm animals. The researched properties have never had a plan to combat bovine brucellosis. 
Management tool proposed to minimize the weakness of no vaccination of all heifers against brucellosis: PDCA cycle

The PDCA cycle (AGUIAR, 2006) is the management tool chosen to minimize this weakness because the problem requires continuous monitoring, since all heifers need to be vaccinated between the ages of three and eight months. It was established that, once implanted, there will be a need for individual control of animals through files and worksheets, which will be in constant use, following a continuous improvement cycle. According to Aguiar (2006), the use of this tool involves four stages, beginning with the problem identification and ending with the evaluation. The PDCA cycle is divided into: Plan (planning), which consists of establishing the goal or target to be achieved; Do (implementation), which is the work of developing and executing the defined tasks; Check (verification of work development) during and after execution; and Action, which transforms the working plan into a new way of accomplishing tasks within the company. It should be used for frequent problems that require constant monitoring and are more complex (ANTUNES; ESSELS, 1999). For the proposal of the solution to the problem, the following recommendation was made:

Planning (Plan): Implantation of an individual file of zootechnical control, blood collection for brucellosis screening and control of entry and exit of animals in the properties.

Implementation (Do): The veterinarian responsible for the properties will collect the blood of each animal and send it to a laboratory accredited by the Ministry of Agriculture, Livestock and Food Supply (MAPA) for diagnosis, where the antigen acidified tamponade (AAT) test (routine test) or the 2-Mercaptoethanol test (a confirmatory test of animals reactive to the AAT test) will be performed. Producers will be trained to organize and complete the individual file and zootechnical record and spreadsheets to obtain full sanitary control of this infectious disease.
Verification (Check): The brucellosis test tends to be confirmed within 48 hours. Moreover, it is necessary to check periodically the vaccination of heifers that will be born and reach the recommended age to receive the vaccine.

Action: Animals that show positive diagnostic tests for brucellosis should be referred for slaughter to establishments with an inspection service. All heifers between three and eight months of age in the herd will be vaccinated against brucellosis with the attenuated vaccine B19. Heifers should be branded with the letter $\mathrm{V}$, accompanied by the final digit of the vaccination year, on the left side of their face to identify and control the vaccinated females. Negative animals will remain in the herd; however, for the properties to be considered free of brucellosis, they must have at least two consecutive negative tests, and recurrent tests will be required. The free monitored property certificate will be issued after obtaining a test with $100 \%$ negative initial sampling, as recommended by the National Program for the Control and Eradication of Brucellosis and Animal Tuberculosis (PNCEBT) of the MAPA (BRASIL, 2006).

\section{Third weakness: inadequate (lean) body condition} of cows at calving

In $68 \%$ of the researched dairy farms, the animals showed low body condition at calving. Body condition evaluation is an important tool for monitoring animals' nutritional status. The evaluation of body condition should be performed often and with special attention to times of calving, peak lactation, and drying. Cows with a poor body condition (lean) produce lighter calves and generally have higher mortality during the lactation period, which compromises the peak lactation. Additionally, the recovery period is longer and there is a significant delay in the appearance of the first post-calving heat (BERGAMASCHI et al., 2012). The body score is a determinant factor for a shorter recovery time of the endometrium and 
faster heat manifestation, promoting a decrease in the calving interval (BARBOSA et al., 2016) and thus increasing the productivity.

A loss of body weight in the pre-calving period and the establishment of a negative energy balance (NEB) may negatively influence the return to heat and ovarian activity (MBAYAHAGA et al., 1998). The deleterious effects of an NEB after calving can be exacerbated if simultaneously there is a substantial loss of body condition in the cows, which is directly associated with a delay in first ovulation and an increase in the number of days required for conception (WILTBANK et al., 2006). Dairy cows have prolonged post-calving anoestrus, usually due to a sum of factors, such as a low body condition score, inadequate nutrition and calf presence (lactation) (SÁ FILHO et al., 2009).
Management tool proposed to understand better the weakness of inadequate (lean) body condition of cows at calving: fishbone diagram

To understand better and solve this problem, the fishbone diagram (ISHIKAWA, 1985) is proposed as a management tool due to the number of variables involved in its resolution and because it is a diagnostic tool. It is known as a cause and effect diagram or Ishikawa diagram and is a graphical tool used to manage and control quality in several processes, especially in industrial production. According to Ishikawa (1985), the diagram composition considers that problems can be classified into seven different types of causes, the 7Ms: machine, method, mother nature, manpower, material, management, and measurement. In some cases, another "M" (money) can be used. In Figure 1 , the proposed model can be observed to solve the weakness inadequate (lean) body condition of cows at calving.

Figure 1. Fishbone diagram as a proposal for the resolution of the weakness of inadequate (lean) body condition of cows at calving

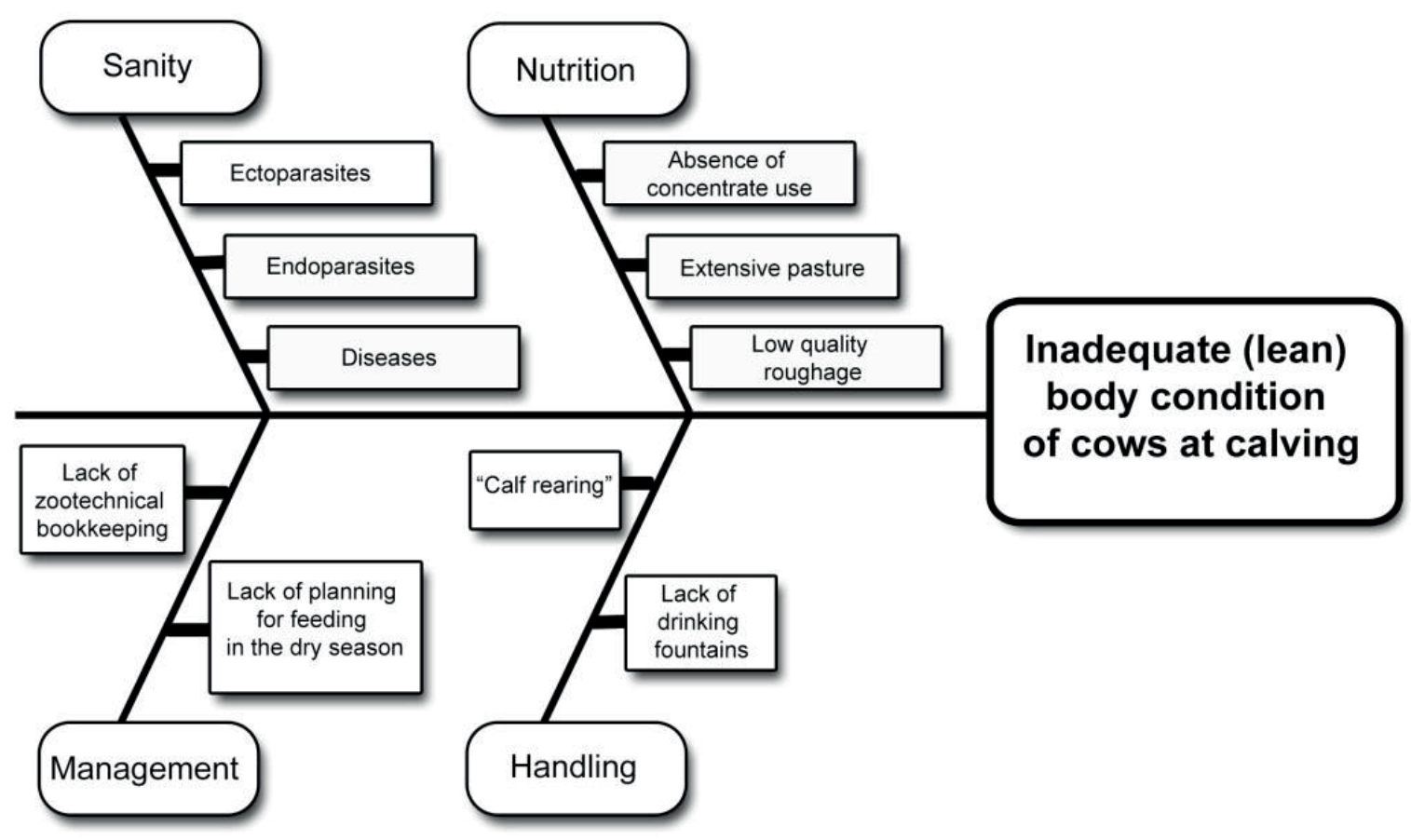


To solve the problem, it is necessary to correct other secondary problems, which lead to the low body condition of animals at calving, such as nutrition, sanity and management (Figure 1). In this respect, other tools, such as $5 \mathrm{~W} 2 \mathrm{H}$, can be used. Regarding nutrition, failures were observed as low quality, low concentration, absence of concentrate use and use of extensive pasture. Regarding sanitation, infestations of endo- and ectoparasites were observed. A lack of drinking fountains and "calf rearing" management in dairy farms were perceived weaknesses related to management. Regarding management, there were problems of a lack of planning for feeding in the dry season and of zootechnical bookkeeping. If these minor items are not resolved, the weakness cannot be corrected. This example demonstrates the complexity of the resolution of the primary problem, but indicates that it is feasible, as proposed in Figure 1.

\section{Applicability of management tools}

The most punctuated weaknesses, through the GUT Matrix, were those selected to be solved in dairy farms (Table 2). The efficiency of the use of the $5 \mathrm{~W} 2 \mathrm{H}$ management tool was $100 \%$; that is, all the properties followed the technical recommendations and installed a drinking fountain (Table 2). The weakness "no vaccination of all heifers against brucellosis" showed less expressive results, because, of the five dairy farms that did not perform the vaccination, three adapted and applied the vaccine B19 to heifers aged between three and eight months. However, two farms did not follow the recommendations, even though this is a mandatory vaccination. It was observed that the application of the PDCA management tool improved the percentage of non-vaccinated animals against brucellosis, reducing it from $16.66 \%$ to $6.66 \%$ (Table 2 ).

The low body condition of cows at calving was the weakness that obtained the lowest response to the application of management tools and technical assistance, since the fishbone diagram is a diagnostic tool and not an action tool, such as $5 \mathrm{~W} 2 \mathrm{H}$. The results did not show differences before and after the use of this tool, because it is believed that the time available for the results to appear was short. Furthermore, to minimize or solve the weaknesses, it would be necessary to apply jointly an action tool for each cause within each sub-cause (nutrition, handling, management and sanitation), because they imply resolution. However, it is suggested that the complexity of the theme, beyond the cost of deployment of the large number of causes (Figure 1) that would need to be solved to achieve results in the main effect, are the main reasons for failure.

It was observed that, when the management tool applied was $5 \mathrm{~W} 2 \mathrm{H}$, excellent results were obtained for the weaknesses, such as: a lack of drinking fountains, diseased heifers not being separated from healthy ones, a low vaccination rate against clostridial diseases, brucellosis tests only when acquiring animals, tuberculosis tests, the absence of a sanitary calendar and no use of soil conservation practices (Table 2). Several of these problems have been fully solved or greatly minimized. It is possible that these were the problems involving a lower cost for resolution or minimization. When the PDCA cycle or fishbone diagram tools were used, the results were not as expressive, because the weaknesses to which they were applied require more time for resolution and the cited tools are organizational and diagnostic tools, respectively, and not intended for resolution; hence, they have different functions. Moreover, this is believed to have occurred due to the low schooling levels and family incomes of rural producers, little technical knowledge, little adoption of technologies, and a lack of continuous technical assistance for the development of dairy farms.

The results show the importance of technical assistance programmes for rural properties. Acre's milk production sector currently has one of the country's worst production indicators, according to data from the IBGE (2015), due to several factors 
that contribute directly to this scenario, such as the low technological level of properties and the absent structure of the production chain. The application of management tools associated with constant and qualified technical assistance is suggested so that the effects of existing weaknesses can be solved or minimized.

Table 2. Results of the applicability of management tools in the correction of problems of the studied dairy farms in the mesoregion of the Acre Valley from March to July 2017.

\begin{tabular}{|c|c|c|c|c|c|}
\hline \multirow{2}{*}{ Weaknesses } & \multicolumn{2}{|l|}{ Before* } & \multicolumn{2}{|c|}{ After** } & \multirow{2}{*}{ Tool used } \\
\hline & $\mathrm{n}=30$ & $\%$ & $\mathrm{n}=30$ & $\%$ & \\
\hline Lack of drinking fountains in pastures & 30 & $100.00^{\mathrm{a}}$ & 0 & $0.00^{\mathrm{b}}$ & $5 \mathrm{~W}_{2} \mathrm{H}^{1}$ \\
\hline $\begin{array}{l}\text { No vaccination of all heifers against bru- } \\
\text { cellosis }\end{array}$ & 5 & $16.66^{\mathrm{a}}$ & 2 & $6.66^{\mathrm{b}}$ & $\mathrm{PDCA}^{2}$ and $5 \mathrm{~W} 2 \mathrm{H}^{1}$ \\
\hline $\begin{array}{l}\text { Inadequate (lean) body condition of cows } \\
\text { at calving }\end{array}$ & 17 & $56.66^{\mathrm{a}}$ & 17 & $56.66^{\mathrm{a}}$ & Fishbone diagram ${ }^{3}$ and $5 \mathrm{~W} 2 \mathrm{H}^{1}$ \\
\hline $\begin{array}{l}\text { Cows dry on their own due to low persis- } \\
\text { tence of lactation }\end{array}$ & 30 & $100.00^{\mathrm{a}}$ & 26 & $86.66^{\mathrm{a}}$ & $\mathrm{PDCA}^{2}$ and $5 \mathrm{~W} 2 \mathrm{H}^{1}$ \\
\hline Calving interval greater than 12 months & 30 & $100.00^{\mathrm{a}}$ & 30 & $100.00^{\mathrm{a}}$ & $\mathrm{PDCA}^{2}$ and $5 \mathrm{~W} 2 \mathrm{H}^{1}$ \\
\hline $\begin{array}{l}\text { Non-realization of zootechnical bookkee- } \\
\text { ping }\end{array}$ & 27 & $90.00^{\mathrm{a}}$ & 19 & $68.33^{\mathrm{a}}$ & $\mathrm{PDCA}^{2}$ and $5 \mathrm{~W} 2 \mathrm{H}^{1}$ \\
\hline $\begin{array}{l}\text { Sick heifers are not separated from heal- } \\
\text { thy animals }\end{array}$ & 20 & $66.66^{\mathrm{a}}$ & 0 & $0.00^{\mathrm{b}}$ & $5 \mathrm{~W} 2 \mathrm{H}^{1}$ \\
\hline $\begin{array}{l}\text { Low vaccination rate against clostridial } \\
\text { diseases }\end{array}$ & 16 & $53.33^{\mathrm{a}}$ & 0 & $0.00^{\mathrm{b}}$ & $5 \mathrm{~W} 2 \mathrm{H}^{1}$ \\
\hline Inadequate herd composition & 30 & $100.00^{\mathrm{a}}$ & 29 & $96.66^{\mathrm{a}}$ & Fishbone diagram ${ }^{3}$ and $5 \mathrm{~W} 2 \mathrm{H}^{1}$ \\
\hline $\begin{array}{l}\text { Performing brucellosis tests only when } \\
\text { animals are acquired }\end{array}$ & 15 & $50.00^{\mathrm{a}}$ & 30 & $100.00^{\mathrm{b}}$ & $5 \mathrm{~W}_{2} \mathrm{H}^{1}$ \\
\hline Non-realization of tuberculosis exams & 8 & $26.66^{\mathrm{a}}$ & 27 & $90.00^{\mathrm{b}}$ & $5 \mathrm{~W}_{2} \mathrm{H}^{1}$ \\
\hline Lack of sanitary calendar & 28 & $93.33^{\mathrm{a}}$ & 7 & $23.33^{\mathrm{b}}$ & $5 \mathrm{~W}_{2} \mathrm{H}^{1}$ \\
\hline $\begin{array}{l}\text { Do not restrict the use of doramectin ba- } \\
\text { sed vermifuge in lactating cows }\end{array}$ & 19 & $63.33^{\mathrm{a}}$ & 26 & $86.66^{\mathrm{b}}$ & $5 \mathrm{~W} 2 \mathrm{H}^{1}$ \\
\hline $\begin{array}{l}\text { The criterion for drying a cow is produc- } \\
\text { tion }\end{array}$ & 29 & $96.66^{\mathrm{a}}$ & 28 & $93.33^{\mathrm{a}}$ & $\mathrm{PDCA}^{2}$ and $5 \mathrm{~W} 2 \mathrm{H}^{1}$ \\
\hline Average infestation of ticks in cows & 22 & $73.33^{\mathrm{a}}$ & 13 & $43.33^{\mathrm{b}}$ & Fishbone diagram ${ }^{3}$ and $5 \mathrm{~W} 2 \mathrm{H}^{1}$ \\
\hline $\begin{array}{l}\text { Average infestation of horn flies in hei- } \\
\text { fers }\end{array}$ & 18 & $60.00^{\mathrm{a}}$ & 8 & $26.66^{\mathrm{b}}$ & Fishbone diagram ${ }^{3}$ and $5 \mathrm{~W} 2 \mathrm{H}^{1}$ \\
\hline Age at first calving of 36 months & 22 & $73.33^{\mathrm{a}}$ & 21 & $70.00^{\mathrm{a}}$ & $\mathrm{PDCA}^{2}$ and $5 \mathrm{~W} 2 \mathrm{H}^{1}$ \\
\hline Do not make heat observation & 22 & $73.33^{\mathrm{a}}$ & 0 & $0.00^{\mathrm{b}}$ & $5 \mathrm{~W} 2 \mathrm{H}^{1}$ \\
\hline Non-use of soil conservation practices & 28 & $93.33^{\mathrm{a}}$ & 25 & $83.33^{\mathrm{a}}$ & $\mathrm{PDCA}^{2}$ and $5 \mathrm{~W} 2 \mathrm{H}^{1}$ \\
\hline $\begin{array}{l}\text { Heifers do not receive concentrate after } \\
\text { the seventh day }\end{array}$ & 29 & $96.66^{\mathrm{a}}$ & 11 & $36.66^{\mathrm{b}}$ & $5 \mathrm{~W}_{2} \mathrm{H}^{1}$ \\
\hline $\begin{array}{l}\text { They did not seek to identify the cause of } \\
\text { abortions }\end{array}$ & 27 & $90.00^{\mathrm{a}}$ & 22 & $73.33^{\mathrm{a}}$ & Fishbone diagram ${ }^{3}$ and $5 \mathrm{~W} 2 \mathrm{H}^{1}$ \\
\hline
\end{tabular}

Caption: * Before $=$ diagnosis performed before the application of management tools; $* *$ After $=$ diagnosis performed after the application of management tools. Different letters on the same row indicate statistical difference according to the McNemar test $(\mathrm{P}<0.05)$. 1: resolution tool; 2: organization tool; 3: diagnostic tool. 
The use of management tools becomes useful within a property, acting in the identification of problems and ordering them according to their severity, urgency and tendency to worsen so that they can be solved. For this purpose, management knowledge is needed for their application to dairy farms. Therefore, the application of tools may pave the way to the construction of a strategic management plan, based on organizational diagnosis methodologies and administration systems to consolidate decision making as well as contributing to human resource training in rural enterprise management.

It is worth mentioning that the entire process of the application of management tools was conducted by qualified and committed technical assistance, since it is believed that it is crucial to associate the tools with technical follow-up for success.

The use of management tools is very effective, since they act from the problem diagnosis, ordering the weaknesses according to their severity, urgency and tendency to worsen and are able to assist in the accomplishment of an action plan and goals to be achieved in the short, medium and long terms. Furthermore, collaboration is expected with Brazilian agriculture and livestock through the generation of knowledge and techniques capable of improving the efficiency and results of agricultural economic activities and may serve as a basis for future research related to the theme.

\section{Conclusions}

It was concluded, therefore, that it is possible to adapt the management tools used in other activities to dairy farming, aiming to correct failures and hence increase profitability. It was also concluded that the use of the GUT Matrix is able to prioritize the actions within a dairy farm. The management tools 5W2H, PDCA and the fishbone diagram obtained expressive results in the resolution of problems within their functions, together with the monitoring of the extensionist technician. The tools can be complementary and will hardly be exclusionary. Regarding the validation of the form used, it was verified that it was fundamental for the accomplishment of the research and that it is able to be used in new diagnostic studies of milk cattle farms.

\section{References}

ADAMS, R. S.; SHARPE, W. E. Water intake and quality for dairy cattle. State College: Penn State Ext. Publ. DAS 95-8, 1995. $62 \mathrm{p}$.

AGUIAR, S. Integração das ferramentas da qualidade ao PDCA e ao programa seis sigma. 2. ed. Nova Lima: INDG, 2006. $172 \mathrm{p}$.

ALVES, I.; REZENDE, S. O.; OLIVEIRA NETO, O. J.; DREES, C.; SANTANA, R. Aplicação do modelo e análise SWOT no diagnóstico estratégico de uma propriedade rural especializada em recria e engorda de bovinos de corte. Revista Administra Ação, Anápolis, v. 1, n. 1, p. 22-39, 2007.

AMORIM, C. M. M.; LIBRELOTTO, L. I.; FERROLI, P. C. M. Gestão ambiental: estudo de caso aplicado numa empresa do setor automobilístico. Revista Gestão e Sustentabilidade Ambiental, Florianópolis, v. 4, n. 2, p. 313-331, 2015.

ANDRADE, S. P.; BOFF, C. D. S. Ferramentas de planejamento para tomada de decisão aplicadas a um microempreendedor individual (MEI). Revista de Contabilidade, Ciência da Gestão e Finanças, Caxias do Sul, v. 2, n. 1, p. 57-85, 2014.

ANTUNES, L. M.; ESSELS, A. Agroqualidade: qualidade total na agropecuária. Porto Alegre: Guaíba Agropecuária, 1999. 117 p.

BARBETTA, P. A. Estatística aplicada às ciências sociais. 7. ed. Florianópolis: Editora da UFSC, 2003. 118 p.

BARBOSA, L. P.; RODRIGUES, J. D.; GUIMARÃES, C.A.A.; TORRES, G. R.; CARVALHO, L. S.; AMORIM, P. A.; DUTRA, M. Influência da condição corporal ao parto no balanço energético e desempenho reprodutivo de cabras leiteiras no pós-parto. Arquivo Brasileiro de Medicina Veterinária e Zootecnia, Belo Horizonte, v. 68, n. 4, p. 1283-1291, 2016.

BEHR, A.; MORO, E. L. S.; ESTABEL, L. B. Gestão da biblioteca escolar: metodologias, enfoques e aplicação de ferramentas de gestão e serviços de biblioteca. Ciência da Informação, Brasília, v. 37, n. 1, p. 32-42, 2008. 
BENEDETTI, E. Água na nutrição de ruminantes. In: Nutrição e alimentação de ruminantes. Cadernos Acadêmicos da FAZU, Uberaba, v. 1, Chap. 4, p. 47-59, 2009.

BERGAMASCHI, M. A. C. M.; MACHADO, R.; BARBOSA, R. T. Eficiência reprodutiva das vacas leiteiras. São Carlos: EMBRAPA Pecuária Sudeste, 2012. 34 p.

BERNUÉS, A.; MANRIQUE, E.; MAZA, M. T. Economic evaluation of bovine brucellosis and tuberculosis eradication programmes in a mountain area of Spain. Preventive Veterinary Medicine, Fort Collins, v. 30, n. 2, p. 137-149, 1997.

BIZINOTO, A. L. Instalações e equipamentos para bovinos de corte. In: SIMPÓSIO GOIANO SOBRE MANEJO E NUTRIÇÃO DE BOVINOS, 4., 2002, Goiânia. Anais... Goiânia: CBNA, 2002. p. 35-54.

BONAMIGO, A.; MELTZ, M. J.; SEHENEM, S.; WINCK, C. A. Manejo dos dejetos de suínos através do sistema de compostagem. Revista em Agronegócio e Meio Ambiente, Maringá, v. 7, n. 2, p. 659-681, 2014.

BOYLES, S.; WOHLGEMUTH, K; FISHER, G. Livestock and water. Fargo: North Dakota State University, 1988. 46 p. (Extension Service Bulletin, AS954).

BRASIL. Ministério de Agricultura, Pecuária e Abastecimento. Programa Nacional de Controle $e$ Erradicação da Brucelose e da Tuberculose Animal (PNCEBT): manual técnico. Brasília: Biblioteca Nacional de Agricultura, BINAGRI, 2006. 76 p.

COLETTI, J.; BONDUELLE, G. M.; IWAKIRI, S. Avaliação de defeitos no processo de fabricação lamelas para pisos de madeira engenheirados com uso de ferramentas de controle de qualidade. Revista Acta Amazônica, Manaus, v. 40, n. 2, p. 135-140, 2010.

CREPALDI, S. A. Contabilidade gerencial. São Paulo: Atlas, 1998.219 p.

FARIAS, A. P. S.; FONTANA, M. E; MORAIS, D. C. Modelo de sistema de informação e decisão para intervenções de reabilitação em redes de distribuição de água. Revista Brasileira de Recursos Hidricos, Porto Alegre, v. 18, n. 1, p. 4-16, 2013.

FISHER, L. D.; VAN BELLE, G. Biostatistics: a methodology for the health sciences. $7^{\text {th }}$ ed. New York: John Wiley and Sons, 1993. 164 p.

GODINHO, R. F.; CARVAlHO, R. C. R. Gestão de sistemas de produção de leite. Ciência. et Praxis, Belo Horizonte, v. 2, n. 1, p. 77-82, 2009.
GUDKOVA, S.; CHEREPANOVA, N.; DUPLYAKOV, D.; GOLOVINA, G.; KHOKHLUNOV, S.; SURKOVA, E.; ROTAR, O.; KONRADI, A.; SHLYAKHTO, E. Lifetime prevalence of transient loss of consciousness in an urban Russian population. Arquivo Brasileiro de Cardiologia, Rio de Janeiro, v. 6, n. 4, p. 382-388, 2016.

IBM Corp. IBM SPSS Statistics for Windows. Version 20.0. Armonk: IBM Corp., 2011.

INSTITUTO BRASILEIRO DE GEOGRAFIA E ESTATÍSTICA - IBGE. Pesquisa de Pecuária Municipal. Rio de Janeiro: Ed. Ministério da Agricultura, 2015. Disponível em: <https://biblioteca.ibge.gov.br/ visualizacao/periodicos/84/ppm_2015_v44_br.pdf $>$. Acesso em: 2 maio 2018.

ISHIKAWA, K. Controle de qualidade total: à maneira japonesa. 3. ed. Rio de Janeiro: Editora: Campus, 1985. $377 \mathrm{p}$.

LISBOA, M. G. P.; GODOY, L. P. Aplicação do método 5W2H no processo produtivo do produto: a joia. Iberoamerican Journal of Industrial Engineering, Florianópolis, v. 4, n. 1, p. 32-47, 2012.

LOPES, M. A.; LIMA, A. L. R.; CARVALHO, F. M.; REIS, R. P.; SANTOS, I. C.; SARAIVA. F. Controle gerencial e estudo da rentabilidade de sistemas de produção de leite na região de Lavras (MG). Ciência e Agrotecnologia, Lavras, v. 28, n. 7, p. 883-892, 2004.

LOPES, M. A.; MORAES, F.; CARVALHO, F. M.; PERES, A. A. C.; BRUHN, F. R. P.; REIS, E. M. B. Efeito do nível tecnológico na rentabilidade de sistemas de produção de leite participantes do programa Balde Cheio: um estudo multicascos. Semina Ciências Agrarias, Londrina, v. 36, n. 4, p. 2909-2922, 2015.

LOPES, M. A.; REIS, E. M. B.; DEMEU, F. A.; MESQUITA, A. A.; ROCHA, A. G. F.; BENEDICTO, G. C. Uso de ferramentas de gestão na atividade leiteira: um estudo de caso no sul de Minas Gerais. Revista Científica de Produção Animal, Areia, v. 18, n. 1, p. 26-44, 2016 a.

LOPES, M. A.; REIS, E. M. B.; FERRAZZA, R. A. Formulário de diagnóstico da propriedade leiteira. Lavras: Universidade Federal de Lavras, 2016b. 17 p. (Boletim técnico, 16).

MARINO, C. T. Água na produção animal. Campo Grande: Macal Nutrição Animal, 2006. 36 p. (Informe técnico).

MASSARONI, I. F.; SCAVARDA, A. J. R. R. Gestão de serviços em bibliotecas públicas: aplicação do $5 \mathrm{~W} 2 \mathrm{H}$ na política de aquisição de acervo. InCID: Revista de Ciência da Informação e Documentação, Ribeirão Preto, v. 6, n. 1, p. 4-16, 2015. 
MBAYAHAGA, J.; MANDIKI, S. N. M.; BISTER, J. L.; PAQUAY, R. Body weight, oestrous and ovarian activity in local Burundian ewes and goats after parturition in the dry season. Animal Reproduction Science, Werribee, v. 51, n. 4, p. 289-300, 1998.

MEIRELES, M. Ferramentas administrativas para identificar, observar e analisar problemas: organizações com foco no cliente. 2. ed. São Paulo: Arte \& Ciência, 2006. 277 p.

MIGUEL, P. A. C. Qualidade: enfoques e ferramentas. São Paulo: Artliber, 2006. 119 p.

MIRANDA, K. L.; PAIVA, R. R. M.; ALMEIDA, A. D. Quem ganha com a certificação de propriedades livres ou monitoradas pelo PNCEBT? Revista Leite Integral, Belo Horizonte, v. 3, n. 1, p. 44-55, 2008.

MOCCI, D.; KEYS, R. D.; SILVEIRA, A. F. Prevalência da brucelose e tuberculose bovina em propriedades da região de São José do Rio Preto-SP. ARS Veterinaria, Jaboticabal, v. 30, n. 2, p. 100-103, 2014.

NOVO, A. L. M.; SCHIFFLER, E. A. Princípios básicos para produção econômica de leite. São Carlos: EMBRAPA Pecuária Sudeste, 2006. 42 p.

OSBORNE, V. R.; HACKER, R. R.; MCBRIDE, B. W. Effects of heated drinking water on the production responses of lactating Holstein and jersey cows. Canadian Journal Animal Science, Ottawa, v. 82, n. 4, p. 267-273, 2002.

PEREIRA, M. N.; RESENDE, J. C.; PEREIRA, R. A. N.; SILVA, H. C. M. Indicadores de desempenho de fazendas leiteiras de Minas Gerais. Arquivo Brasileiro de Medicina Veterinária e Zootecnia, Belo Horizonte, v. 68, n. 4, p. 1033-1042, 2016.

POESTER, F. P.; SAMARTINO, L. E.; SANTOS, R. L. Pathogenesis and pathobiology of brucellosis in livestock. Scientific and Technical Review of the Office International des Epizooties, Paris, v. 32, n. 3, p. $105-$ $115,2013$.

POLACINSKI, E.; VEIGA, R. S.; SILVA, V. B.; TAUCHEN, J.; PIRES, M. R. Implantação dos 5Ss e proposição de um SGQ para uma indústria de erva-mate. Revista ADMpg Gestão. Estratégica, Ponta Grossa, v. 6, n. 2, p. 71-78, 2012.
RIBEIRO, L.; BENEDETTI, E. A importância da qualidade da água na nutrição de ruminantes. Cadernos Acadêmicos da FAZU, Uberaba, v. 1, Chap. 2, p. 23-34, 2011.

ROBERTI, F.; SANTANA, S. Melhoramentos e padronização de processos em restaurante. Revista $E-R A C$, Rio de Janeiro, v. 3, n. 1, p. 73-82, 2013.

SÁ FILHO, O. G.; VILELA, E. R.; GEARY, T. W.; VASCONCELOS, J. L. M. Strategies to improve fertility in postpartum multiparous Bos indicus cows submitted to a fixed-time insemination protocol with gonadotropinreleasing hormone and prostaglandin F2alpha. Journal of Animal Science, Champaign, v. 87, n. 9, p. 2806-2814, 2009.

SANTOS, R. L.; MARTINS, T. M.; BORGES, A. M.; PAIXÃO, T. A. Economic losses due to bovine brucellosis in Brazil. Pesquisa Veterinária Brasileira, Rio de Janeiro, v. 33, n. 6, p. 759-764, 2013.

SILVA, M. F.; PEREIRA, J. C.; GOMES, S. T.; NASCIF, C.; GOMES, A. P. Avaliação dos indicadores zootécnicos e econômicos em sistemas de produção de leite. Revista de Política Agrícola, Brasília, v. 24, n. 1, p. 62-73, 2015.

SOUZA, A. C.; ANDRADE, L. S. S.; SOUSA, D. S. L. Orientações para o descarte responsável de medicamentos de uso veterinário. In: JORNADA DE ENSINO, PESQUISA E EXTENSÃO, 13., 2014, Recife. Anais... Recife: UFRPE, 2014. p. 161-163.

TAVARES, J. E.; BENEDETTI, E. Água: uso de bebedouros e sua influência na produção de bovinos em pasto. Cadernos Acadêmicos da FAZU, Uberaba, v. 2, chap. 7, p. 152-157, 2012.

WILTBANK, M.; LOPEZ, H.; SARTORI, H. R.; SANGSRITAVONG, $\mathrm{S}$. Changes in reproductive physiology of lactating dairy cows due to elevated steroid metabolism. Theriogenology, Philadelphia, v. 65, n. 1, p. 17-29, 2006.

WOLF, C. A. Dairy farmer use of price risk management tools. Journal of Dairy Science, Champaign, v. 95, n. 7, p. 4176-4183, 2012.

WORLD HEALTH ORGANIZATION - WHO. World health organization guidelines for drinking-water quality. $2^{\text {th }}$ ed. Geneva: WHO Library Cataloguing-in-Publication Data, 1993. 217 p. 
